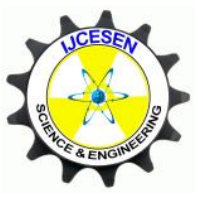

Copyright (C) IJCESEN
International Journal of Computational and

Experimental $\boldsymbol{S}$ cience and Engineering

(IJCESEN)

Vol. 4-No.3 (2018) pp. 9-14

http://dergipark.gov.tr/ijcesen

Research Article

\title{
Resistivity and Seismic Refraction Studies on Kısıklı Landslide (Antalya, Turkey)
}

\author{
Sedat YILMAZ, Züheyr KAMACI \\ Süleyman Demirel University, Engineering Faculty, Geophysical Engineering Department, Isparta, Turkey \\ * Corresponding Author : zuheyrkamaci@ sdu.edu.tr \\ ORCID: 0000-0002-2331-0162
}

\section{Article Info: \\ DOI: $10.22399 /$ ijcesen. 348792 \\ Received : 2 November 2017 \\ Accepted : 31 May 2018 \\ Keywords : \\ Landslide \\ Vertical electrical sounding \\ Seismic refraction \\ Turkey}

\begin{abstract}
:
When natural slope is disturbed by human activity such as road construction and infrastructure, continuous landslide monitoring is important to prevent loss of material and life. Therefore, this study aims to determine the landslide material, the possible sliding surface and the influence of groundwater on the landslide occurrence. Low cost monitoring landslide is performed which is vertical electrical sounding (VES) and seismic refraction methods. The case study area is located in the district of K1s1kl1 (Antalya province) in the Mediterranean Region of Turkey. VES survey were performed using Schlumberger electrode array at six locations. VES results interpretation leads to detect of maximum five geoelectrical layers. First, second and third layers represent saturated and permeable layer, while fourth and fifth layers correspond to an impermeable layer. Seismic refraction measurements were carried out on three profiles. Low velocity and elastic parameters relatively correspond to the permeable materials in near surface with thickness about 4-5 m higher porosity. The integrated of VES and seismic surveys allow mapping the weathered material at depth and providing depth information of the sliding surface which occurs at a depth between approximately $5 \mathrm{~m}$ and $20 \mathrm{~m}$.
\end{abstract}

\section{Introduction}

Landslide is one of natural hazard that probably impact thousands of deaths and losses of billions of dollars every year [1]. It has different properties according to the cause of occurrence and shape [2]. It occur in the form of slipping, flowing and falling along a certain surface [3]. Therefore landslides are geologic complex formed from the combination of changes in contrast and physical values possessed by the layer [4].

Because of the high cost of geotechnical methods based on direct research, geophysical surveys are the best way to study landslides by determining landslide characteristics [5-7]. Therefore, relatively low cost and noninvasive geophysical methods provide new deals for promptly survey of large areas and produce detailed information about the landslide internal structure [8-10]. Vertical electrical sounding (VES/one-dimensional resistivity) and seismic refraction from field geophysical exploration methods are widely used to investigate the landslide area [11-16]. The success of the resistivity method is connected directly to the electrical resistivity contrast of different lithological units (clay, marl, limestone and etc [13, 17-19]. The first arrivals and their corresponding travel times of seismic refraction are analyzed. With survey of a landslide with geophysical methods may be determined the thickness and lateral extension of slip material, the possible sliding surface, the bedrock depth, the distribution of various materials and the status of groundwater within the slip mass [17, 18, 20-27]

In this study, a landslide occurred after heavy rainfall has been investigated. The maximum amount of rainfall in the landslide area formed between November and February 2010. This landslide occurred on February 2010 in Kisıkl1 district of Sarıabalı village of Serik town, Antalya 
in Turkey. Annual precipitation between 2008 and 2010 was $273 \mathrm{~mm}, 1399 \mathrm{~mm}$ and $1436 \mathrm{~mm}$, respectively. There was not available daily rainfall data before landslide. In addition, the landslide had taken place after the huge Manavgat-Serik forest fire that broke out in the summer of 2008. Using VES and seismic refraction methods, the thickness of the mass causing landslide, water content, the sliding surface and bedrock structure has been uncovered.

\section{Location and Geology}

Study area is located in K1s1klı district of Sarıabalı village of Serik town of the province of Antalya in Mediterranean Region of Turkey (Fig. 1). Kisıkl1 landslide showing an inclination of about $17^{\circ}$ is approximately $380 \mathrm{~m}$ long, about $90-110 \mathrm{~m}$ wide and in an environment with an altitude ranging from $50 \mathrm{~m}$ to $160 \mathrm{~m}$. Many man-made structures, such as road along slope, a greenhouse site and several buildings, have been largely damaged by landslide (Fig. 2).

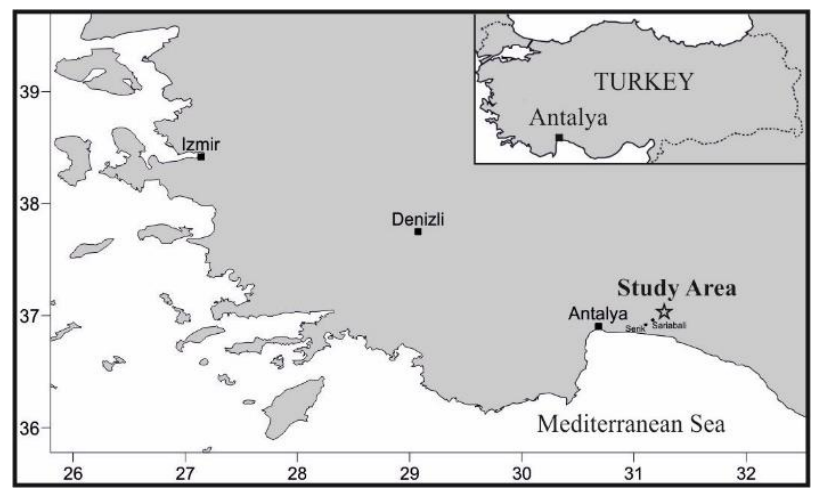

Figure 1. Study area.

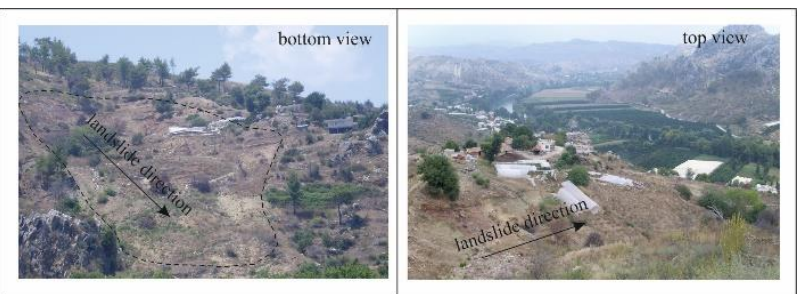

Figure 2. Photographs of the site showing the landslide scarp and damaged structures.

Kıs1klı District includes the Ophiolitic Melange of the Antalya Nappes, the Miocene Tepekli Conglomerates and the Karpuzçay Formation [2830]. The Ophiolitic Melange is mainly composed of limestone blocks, sandstone, marl, chert, shale, serpentinites. The Tepekli Formation around Sarrabalı region outcrops especially along the eastern margin of the Antalya Nappes and consists mainly of well-rounded clastic materials intercalated with mudstones. In places, reefal limestones embedded within the conglomerates can be observed in the area. The Antalya Basin, separated into three sub-basins such as the Manavgat, Köprüçay and Aksu, occurs within the Isparta Angle (Fig. 3) [30]. The Köprüçay Basin including the study area is separated from the Aksu Basin by the late Miocene Aksu Thrust and exists in the central position within the Antalya Basin [31, 32]. The Karpuzçay Formation includes mudstone, siltstone, conglomerates, detritic limestones and rests over the Tepekli Formation [33].

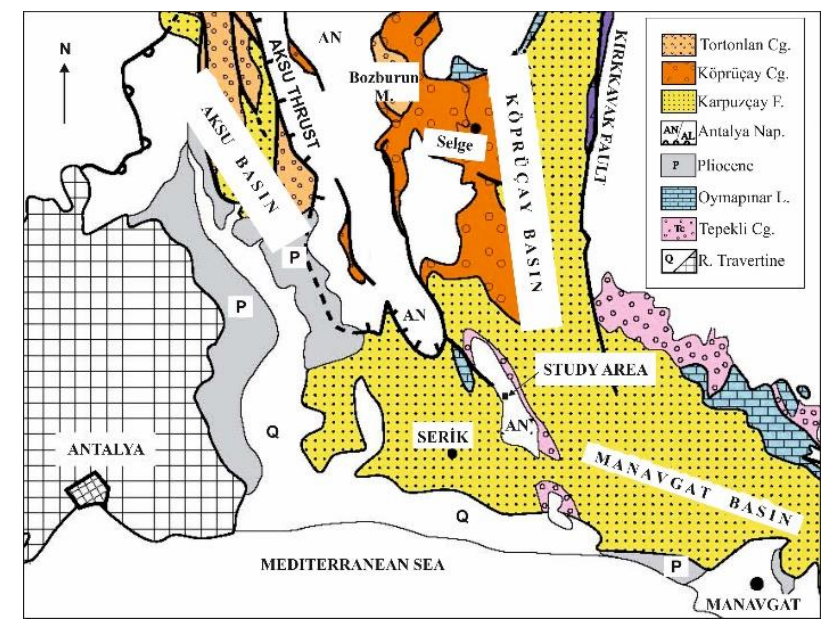

Figure 3. Geology map of the East area of Antalya (modified after Deynoux et. al., 2005).

\section{Data Collection and Processing}

The vertical electrical sounding (VES) method provides one-dimensional (1-D) underground information about the vertical electrical resistivity variation. The classic technique for field VES application is to use Schlumberger electrode array. Five Schlumberger stations were located inside landslide while the remaining one halfSchlumberger station is out landslide area (Fig. 4). Maximum current electrode interval ranges between $100 \mathrm{~m}$ and $150 \mathrm{~m}$. VES Schlumberger data were inverted to their equivalent 1-D models composed of horizontal layers using modeling procedures. An algorithm developed by Zohdy [34] was first used to invert the field VES data. Then IPI2win software [35] was used to improve the first interpreted results.

The seismic refraction method, which benefits from waves traveling in different parts of the underground, is capable of mapping the boundaries between layers characterized by different seismic velocities. Seismic refraction is a quantitative technique that it provides the seismic velocities as well as determining the depths of different subsurface layers. Two kinds of seismic waves, 
namely the P-wave and the S-wave, can assist in the interpretation of geological layers. Three seismic refraction profiles were performed both forward and reverse shooting techniques. The seismic stations were located inside active landslide site (Fig. 4). Seismic refraction data were analyzed graphically, and P- and S- velocities were obtained from slopes of the time-distance graphs. Depths of the layers using travel time equations derived as a function of velocity were computed. Elastic parameters such as modulus of elasticity and Poisson's ratio that describe the subsurface material were calculated by using $\mathrm{P}$ - wave and $\mathrm{S}$ - wave velocities.

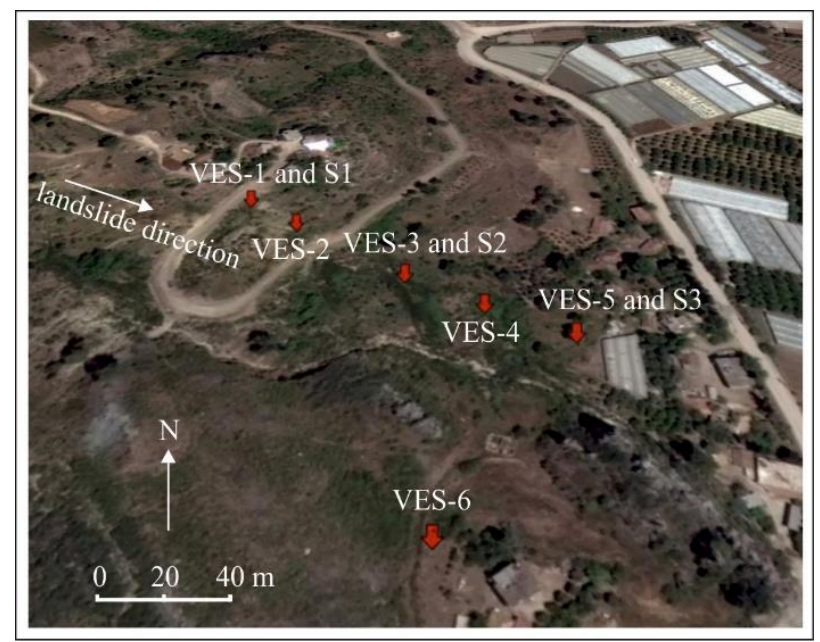

Figure 4. Location of the measurement stations; six vertical electrical sounding (VES-1,VES-2, VES-3, VES4, VES-5 and VES-6) and three seismic refraction (S1, S2 and S3) stations.

\section{Results and Discussion}

Fig. 5 shows 1-D earth models from the resistivity data carried out at stations VES-1, VES-2, VES-3, VES-4, VES-5 and VES-6. Black lines are field data. Blue lines are 1-D models. Red lines show data calculated from 1-D models. The VES modeling results show that the shallow subsurface in the landslide area can be represented by 3 or 5 layers.

The first geoelectrical layer for VES-1 is characterized by mean $20 \Omega \mathrm{m}$ resistivity with thickness of $3 \mathrm{~m}$. The second geoelectrical layer showed to be lower electrical resistivity value (approximately $12 \Omega \mathrm{m}$ with thickness of $12 \mathrm{~m}$ ). The relatively high resistivity value for bottom layer was observed to be about $50 \Omega \mathrm{m}$. The first layer for VES-2 is characterized by mean $60 \Omega \mathrm{m}$ resistivity with thickness of $3 \mathrm{~m}$. The remained layers showed to be lower electrical resistivity values (between 17-30 $\Omega \mathrm{m}$ ). The first geoelectrical layer for mid-point VES-3 is characterized by mean $100 \Omega$ m resistivity value with thickness of $2.3 \mathrm{~m}$. The mid-geoelectric layer showed to be lower electrical resistivity value (between $23 \Omega \mathrm{m}$ and 35 $\Omega \mathrm{m}$ with thickness of approximately $30 \mathrm{~m}$ ). Bottom layer resistivity was observed to be on the rise. The first layer for VES-4 is characterized by mean 120 $\Omega \mathrm{m}$ resistivity value with thickness of $1 \mathrm{~m}$. The remained layers showed to be lower electrical resistivity values (between 15-35 $\Omega \mathrm{m}$ ). The first geoelectrical layer for VES-5 is characterized by mean $80 \Omega$ m resistivity value with thickness of 1.7 $\mathrm{m}$. The mid-geoelectric layer showed to be lower electrical resistivity value (between $20 \Omega \mathrm{m}$ and 30 $\Omega \mathrm{m}$ with thickness of approximately $23 \mathrm{~m}$ ). The bottom layer showed to be higher resistivity with approximately $100 \Omega \mathrm{m}$. The higher resistivity values about $1300 \Omega \mathrm{m}$ were observed for VES-6 outside the landslide disturbed area.

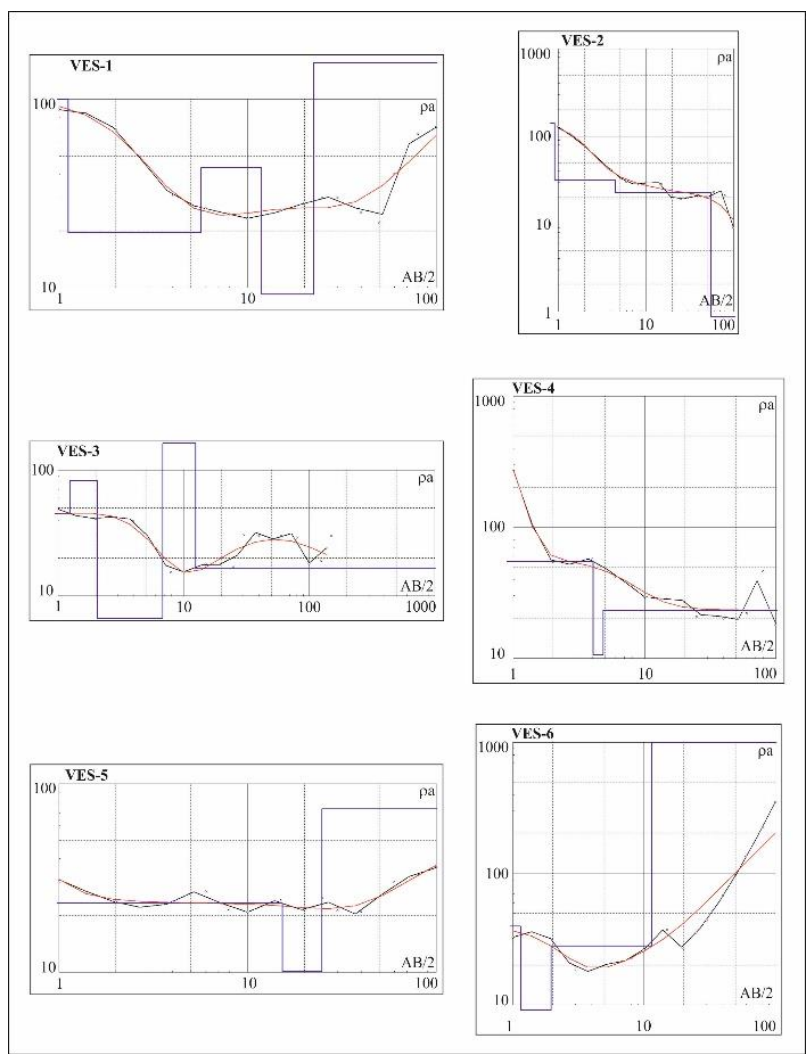

Figure 5. The modelled VES curves using 1-D interpretation. Measured data (black curves), calculated data from 1-D model (red curves) and interpreted 1-D models (blue lines).

Fig. 6 shows the resistivity section obtained from combining the VES results. The section illustrates the lateral and vertical variation of electrical resistivity along the profile in landslide area. In particular, the relatively low resistivity values between $13 \Omega \mathrm{m}$ and $30 \Omega \mathrm{m}$ correspond to impermeable materials, which are clay and water. 
The relatively higher values than $30 \Omega \mathrm{m}$ resistivity correspond to the saturated mobilized landslide materials at a thickness between $5 \mathrm{~m}$ and $20 \mathrm{~m}$.

Table 1 shows the $\mathrm{P}$ - wave and $\mathrm{S}$ - wave velocities, estimated thickness of the layer and dynamic elastic parameter as Poisson's ratio and modulus of elasticity concluded from the seismic records of three stations inside the landslide site. At seismic stations S1, S2 and S3 on the first layer, average seismic P-wave velocities were stated to be 446 , 379 and $571 \mathrm{~m} / \mathrm{s}$. Their corresponding thicknesses were noted to be $5 \mathrm{~m}, 4 \mathrm{~m}$ and $4 \mathrm{~m}$, respectively. The second layer, average seismic P-wave velocities were stated to be 1307,1475 and 1361 $\mathrm{m} / \mathrm{s}$, and their corresponding thicknesses were noted to be $13 \mathrm{~m}, 11 \mathrm{~m}$ and $11 \mathrm{~m}$, respectively. Average seismic P-wave velocities for the third layer were stated to be 2072, 2938 and $1996 \mathrm{~m} / \mathrm{s}$. Take into account, the modulus of elasticity is more sensitive to porosity changes than seismic wave velocities [36, 37]. This results in the assumption that the decrease in the modulus of elasticity and velocities in near surface is caused by high porosity. The Poisson distribution has values ranging from 0.08 to 0.43 (Table 1). The low Poisson's ratio (about 0.1) indicate that the material is silty clay and dry, while the high values (about 4 and above) indicate that the water content of the material is high.

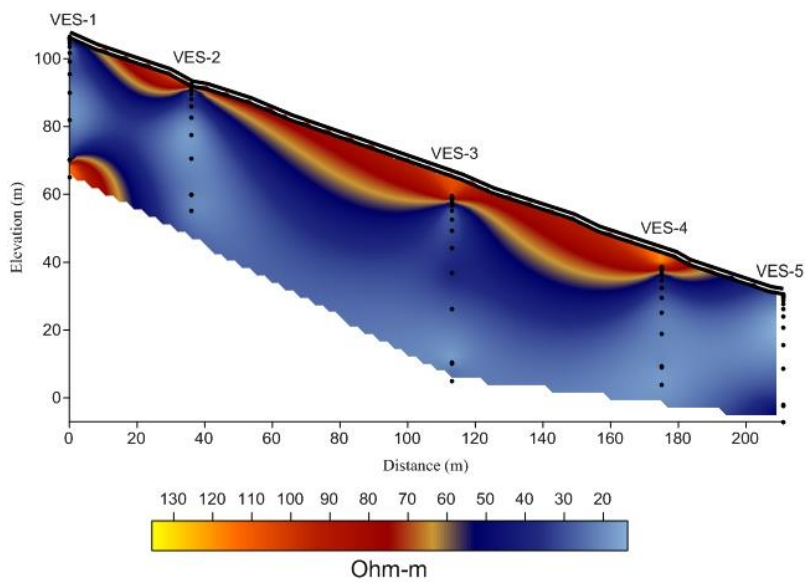

Figure 6. Resistivity cross-section obtained from five modeled VES results.

Table 1. Summary of seismic refraction results.

\begin{tabular}{|c|c|c|c|c|c|c|c|}
\hline \multirow{2}{*}{ Parametric description } & \multirow{2}{*}{ Layer } & \multicolumn{2}{|c|}{ S1 station } & \multicolumn{2}{|c|}{ S2 station } & \multicolumn{2}{|c|}{ S3 station } \\
\hline & & Forward & Reverse & Forward & Reverse & Forward & Reverse \\
\hline P-wave velocity $(\mathrm{m} / \mathrm{s})$ & & 446 & 446 & 379 & 379 & 571 & 571 \\
\hline S-wave velocity $(\mathrm{m} / \mathrm{s})$ & & 302 & 302 & 246 & 246 & 328 & 328 \\
\hline Modulus of elasticity $\left(\mathrm{kg} / \mathrm{cm}^{2}\right)$ & 1 & 2945,79 & 2797,73 & 2062,37 & 1880,61 & 4046,55 & 4088,03 \\
\hline Estimated thickness (m) & & 5 & 5 & 4 & 4 & 4 & 4 \\
\hline Poisson's ratio & & 0,08 & 0,08 & 0,14 & 0,14 & 0,25 & 0,25 \\
\hline P-wave velocity $(\mathrm{m} / \mathrm{s})$ & & 1307 & 1307 & 1475 & 1475 & 1361 & 1361 \\
\hline S-wave velocity $(\mathrm{m} / \mathrm{s})$ & & 611 & 611 & 523 & 523 & 626 & 626 \\
\hline Estimated thickness (m) & 2 & 13 & 13 & 11 & 11 & 11 & 11 \\
\hline Modulus of elasticity $\left(\mathrm{kg} / \mathrm{cm}^{2}\right)$ & & 18929,40 & 18929,40 & 15008,98 & 15008,98 & 20155,97 & 20155,97 \\
\hline Poisson's ratio & & 0,36 & 0,36 & 0,43 & 0,43 & 0,37 & 0,37 \\
\hline P-wave velocity $(\mathrm{m} / \mathrm{s})$ & & 2072 & 2072 & 2938 & 2938 & 1996 & 1996 \\
\hline S-wave velocity $(\mathrm{m} / \mathrm{s})$ & 3 & 864 & 864 & 1205 & 1020 & 1020 & 1020 \\
\hline Modulus of elasticity $\left(\mathrm{kg} / \mathrm{cm}^{2}\right)$ & 3 & 43552,85 & 43552,85 & 33139,71 & 23745,15 & 57053,65 & 57053,65 \\
\hline Poisson's ratio & & 0,39 & 0,39 & 0,40 & 0,43 & 0,32 & 0,32 \\
\hline
\end{tabular}

Integrated interpretation of the vertical electrical sounding and the seismic refraction tests revealed the internal structure of the disturbed landslide zone. Fig. 7 shows the slope section interpreted from the integration of two techniques. The slope cross-section permits to clearly define the slip/sliding surface, the thickness of the saturated landslide material and an impermeable layer consisting of clay and water.

\section{Conclusion}

Based on the vertical electrical soundings, subsurface in landslide disturbed area is represented by 3-5 geoelectrical layers characterized to be electrical resistivity values ranging from $10 \Omega \mathrm{m}$ and $120 \Omega \mathrm{m}$ within a total depth of $40 \mathrm{~m}$. On the other hand, the resistivity values outside the landslide disturbed area were observed to be higher. The resistivity section obtained from the VES results illustrates the lateral and vertical variations in electrical resistivity. The relatively low resistivity values between $13 \Omega \mathrm{m}$ and $30 \Omega \mathrm{m}$ correspond to impermeable materials, which are determined by content of clay and water, 
particularly. The relatively higher values than 30 $\Omega \mathrm{m}$ resistivity correspond to the saturated mobilized landslide materials at a thickness between $5 \mathrm{~m}$ and $20 \mathrm{~m}$.

According to the results of the seismic refraction survey, the depth of about $15 \mathrm{~m}$ of subsurface in the landslide site is represented by 3 seismic layers. The layers within the landslide disturbed site are characterized by that the P- and S- velocities between 379-2938 $\mathrm{m} / \mathrm{s}$ and 246-1020 m/s respectively. The decrease in seismic wave velocities and the modulus of elasticity in near surface is caused by high porosity.

The sliding surface between saturated and impermeable zones is at a depth between $5 \mathrm{~m}$ and $20 \mathrm{~m}$ with $1.5 \mathrm{~m}$ of soil material overlying between $3.5 \mathrm{~m}$ and $18.5 \mathrm{~m}$ of the mobilizing landslide material, which is presence of saturated and permeable material.

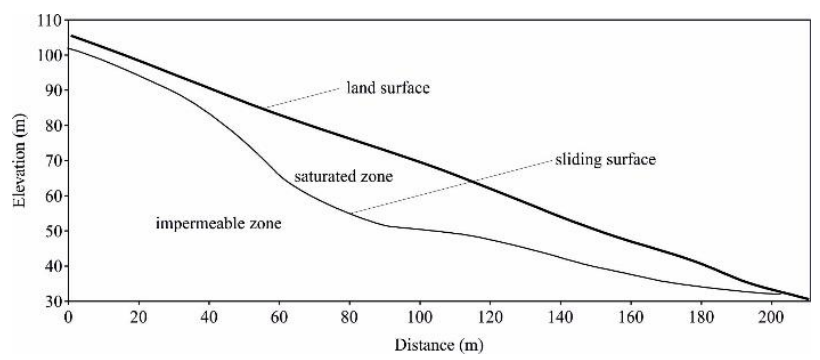

Figure 7. The landslide section obtained from the analysis of resistivity and seismic data.

Because of landslide occur after a huge ManavgatSerik forest fire (summer 2008), future research is important for understanding landslide behavior in that particular area.

The integrated interpretation of 1-D electrical resistivity and seismic refraction tests is useful to figure out the subsurface structure in landslide direction. The investigation results will provide information for a stability assessment of the landslide area in the future.

\section{References}

[1] Klose M., B.Damm, B.Terhorst "Landslide cost modeling for transportation infrastructures: a methodological approach" Landslides. 12 (2014) 321-334

[2] Samia J., A.Temme, A.Bregt, J.Wallinga, F.Guzzetti, F.Ardizzone, et al. "Do landslides follow landslides? Insights in path dependency from a multi-temporal landslide inventory" Landslides. (2016) 1-12

[3] Yamao M., R.Sidle, T.Gomi, F.Imaizumi "Characteristics of landslides in unwelded pyroclastic flow deposits, southern Kyushu, Japan" Natural Hazards and Earth System Sciences. 16 (2016) 617-627
[4] Van Westen C.J. "National Scale Landslide Susceptibility Assessment for Saint Lucia" CHARIM Caribbean Handbook on Risk Information Management, World Bank GFDRR, ACP-EU Natural Disaster Risk Reduction Program. (2016)

[5] Jomard H., T.Lebourg, E.Tric "Identification of the gravitational boundary in weathered gneiss by geophysical survey: La Clapière landslide (France)" Journal of Applied Geophysics. 62 (2007) 47-57

[6] Lee C., C.H.Yang, H.C.Liu, K.L.Wen, Z.B.Wang, Y.J.Chen "A Study of the hydrogeological environment of the lishan landslide area using resistivity image profiling and borehole data" Engineering Geology. 98 (2008) 115-125

[7] Popescu M., R.D.Şerban, P.Urdea, A.Onaca "Conventional geophysical surveys for landslide investigations: two case studies from Romania" Carpathian Journal of Earth and Environmental Sciences. 11-1 (2016) 281-292

[8] Bogoslovsky V.A., A.A.Ogilvy "Geophysical methods for the investigation of landslides" Geophysics. 42 (1977) 562-571

[9] Cosenza P., E.Marmet, F.Rejiba, Y.J.Cui, A.Tabbagh, Y.Charlery "Correlations between geotechnical and electrical data: A case study at Garchy in France" Journal of Applied Geophysics. 60 (2006) 165-178

[10] Ling C., Q.Xu, Q.Zhang, J.Ran, H.Lv “Application of electrical resistivity tomography for investigating the internal structure of a translational landslide and characterizing its groundwater circulation (Kualiangzi landslide, Southwest China)" Journal of Applied Geophysics. 131 (2016) 154-162

[11] Fisseha F., G.Mewa "Road failure caused by landslide in north Ethiopia: A case study from Dedebit-Adi-Remets road segment" Journal of African Earth Sciences. 118 (2016) 65-74

[12] Martínez-Moreno FJ., F.A.Monteiro-Santos, J.Madeira, I.Bernardo, A.Soares, M.Esteves et al. "Water prospection in volcanic islands by Time Domain Electromagnetic (TDEM) surveying: The case study of the islands of Fogo and Santo Antão in Cape Verde" Journal of Applied Geophysics. 134 (2016) 226-234

[13] Yalcinkaya E., H.Alp, E.Ozel, E.Gorgun, S.Martino, L.Lenti et al. "Near-surface geophysical methods for investigating the Buyukcekmece landslide in Istanbul, Turkey" Journal of Applied Geophysics. 134 (2016) 23-35

[14] Confuorto P., D.Di Martire, G.Centolanza, R.Iglesias, J.J.Mallorqui, A.Novellino et al. "Postfailure evolution analysis of a rainfall-triggered landslide by multi-temporal interferometry SAR approaches integrated with geotechnical analysis" Remote Sensing of Environment. 188 (2017) 51-72

[15] Tábořík P., J.Lenart, V.Blecha, J.Vilhelm, O.Turský "Geophysical anatomy of counter-slope scarps in sedimentary flysch rocks (Outer Western Carpathians)" Geomorphology. 276 (2017) 59-70 
[16] Yıldırım E., R.Saatçılar, S.Ergintav "Estimation of seismic quality factor: Artificial neural networks and current approaches" Journal of Applied Geophysics. 136 (2017) 269-278

[17] Akpan A.E., A.O.Ilori, N.U.Essien "Geophysical investigation of Obot Ekpo Landslide site, Cross River State, Nigeria" Journal of African Earth Sciences. 109 (2015) 154-167

[18] Perrone A., A.Iannuzzi, V.Lapenna, P.Lorenzo, S.Piscitelli, E.Rizzo et al. "High-resolution electrical imaging of the Varco d'Izzo earthflow (southern Italy)" Journal of Applied Geophysics. 56 (2004) 17-29

[19] Stan D., I.Stan-Kłeczek “Application of electrical resistivity tomography to map lithological differences and subsurface structures (Eastern Sudetes, Czech Republic)" Geomorphology. 221 (2014) 113-123

[20] Carpentier S., M.Konz, R.Fischer, G.Anagnostopoulos, K.Meusburger, K.Schoeck "Geophysical imaging of shallow subsurface topography and its implication for shallow landslide susceptibility in the Urseren Valley, Switzerland" Journal of Applied Geophysics. 83 (2012) 46-56

[21] Chambers J.E., P.B.Wilkinson, O.Kuras, J.R.Ford, D.A.Gunn, P.I.Meldrum et al. "Three-dimensional geophysical anatomy of an active landslide in Lias Group mudrocks, Cleveland Basin, UK" Geomorphology. 125 (2011) 472-484

[22] Grandjean G., J.C.Gourry, O.Sanchez, A.Bitri, S.Garambois "Structural study of the Ballandaz landslide (French Alps) using geophysical imagery" Journal of Applied Geophysics. 75 (2011) 531-542

[23] Hack R. "Geophysics for slope stability" Surveys in Geophysics. 21 (2000) 423-448

[24] Hibert C., G.Grandjean, A.Bitri, J.Travelletti, J.P.Malet "Characterizing landslides through geophysical data fusion: example of the La Valette landslide (France)" Engineering Geology. 128 (2012) 23-29

[25] McCann D.M., A.Forster "Reconnaissance geophysical methods in landslide investigations" Engineering Geology. 29 (1990) 59-78

[26] Yilmaz S. "A case study of the application of electrical resistivity imaging for investigation of a landslide along highway" International Journal of the Physical Sciences. 6-24 (2011) 5843-5849

[27] Y1lmaz S., C.Narman "2-D electrical resistivity imaging for investigating an active landslide along a ridgeway in Burdur region, southern Turkey" Arabian Journal of Geosciences. 8-5 (2015) 33433349

[28] Akay E., S.Uysal "Post-Eocene tectonics of the Central Taurus Mountains" MTA Dergisi, 108 (1998) 23-34

[29] Çiner A., M.Karabıyıkoğlu, O.Monod, M.Deynoux, S.Tuzcu "Late Cenozoic sedimentary evolution of the Antalya Basin, southern Turkey" Turkish Journal of Earth Sciences. 17 (2007) 1-41
[30] Deynoux M., Ç.Attila, M.Olivier, M.Karabıyıkoglu, G.Manatschal, S.Tuzcu "Facies architecture and depositional evolution of alluvial fan to fan-delta complexes in the tectonically active Miocene Köprüçay Basin, (Isparta Angle, Turkey)" Sedimentary Geology. 173 (2005) 315-343

[31] Monod O., M.Deynoux, M.Karabiyikoglu, A.Çiner, C.Kuzucuoglu, G.Manatshal, S.Tuzcu, A.Hakyemez, M.Moullade "Enregistrement se'dimentaire de l'activite' de la faille de Kirkkavak dans le bassin mioce`ne du Köprü Çay (Turquie meridionale)" $18 \mathrm{e}$ Re'union annuelle des Sciences de la Terre (2000) Paris p.199

[32] Monod O., G.Manatschal, M.Deynoux, A.Çiner, M.Karabiyikoglu, S.Tuzcu, C.Kuzucuoglu "Neogene morphotectonics in the Köprü Basin (Isparta Angle, Southern Turkey)" 11th Eug Meeting (2001) Strasbourg p.524

[33] Monod O., M.Karabiyikoglu, M.Deynoux, A.Çiner, G.Manatschal, S.Tuzcu, C.Kuzucuoglu, M.Moullade, A.Hakyemez, M.C.Janin, J.F.Babinot "Sedimentation, tectonics and geomorphology in the Neogene Antalya Basins: a synthetic outlook" 1st International Symposium of the Faculty of Mines (Itu) on Earth Sciences and Engineering (2002) Istanbul p.177

[34] Zohdy A.A.R. "A new method for the automatic interpretation of Schlumberger and Wenner sounding curves" Geophysics. 54 (1989) 245-253

[35] Shevnin V.A., I.N.Modin "IPI2win ver. 3.0.1- 1D interpretation of VES profile" Moscow State University (2003) Moscow

[36] Kirsch R. "Groundwater geophysics-A tool for hydrogeology" Springer (2006) Berlin

[37] Han D.H., A.Nur, D.Morgan "Effects of porosity and clay content on wave velocities in sandstones" Geophysics. 51 (1986) 2093-2107 